CUADERNOS DE ESTUDIOS GALLEGOS, LXVI Núm. 132 (enero-diciembre 2019), págs. 177-201

ISSN: 0210-847X

https://doi.org/10.3989/ceg.2019.132.06

\title{
HIJOS DEL MAR. LA SIRENA EN EL MITO FUNDACIONAL DE LOS MARIÑO (SIGLOS XIV-XVII)*
}

\author{
Abel LoRENZO RoDríGUEZ \\ Universidad de Santiago de Compostela \\ ORCID iD: http://orcid.org/0000-0002-3845-1013
}

\begin{abstract}
* Este artículo es fruto del período de investigación desarrollado durante los meses de septiembre y octubre de 2017 en el Instituto de Estudios Gallegos Padre Sarmiento (CSIC-XuGa) por la beca JAE-Intro del CSIC (AEINT17 EX 0307) dentro del grupo de investigación Historia social del poder desde la Edad Media enmarcado en los proyectos de investigación Linaje, parentela y poder: la pirámide nobiliaria gallega (siglos XIII al XV) (II) (MINECO, Plan Estatal de Investigación Científica y Técnica y de Innovación 2013-2016. Ref. HAR2013-42985-P), del que es investigador principal el Dr. Eduardo Pardo de Guevara y Valdés y La casa señorial en Galicia (siglos XIII-XVI). Materiales para su estudio, HAR2017-82480-P, financiado por el Ministerio de Ciencia, Innovación y Universidades, la Agencia Estatal de Investigación (AEI) y el Fondo Europeo de Desarrollo Regional (FEDER) (Programa Estatal de Fomento de la Investigación Científica y Técnica de Excelencia. Subprograma Estatal de Generación de Conocimiento), del que es investigador principal el Dr. Pablo S. Otero Piñeyro Maseda.
\end{abstract}

Copyright: @ 2019 CSIC. La edición electrónica de esta revista se distribuye bajo los términos de una licencia de uso y distribución Creative Commons Reconocimiento 4.0 Internacional (CC BY 4.0).

Cómo citar/Citation: Abel Lorenzo Rodríguez, "Hijos del Mar. La sirena en el mito fundacional de los Mariño (siglos XIV-XVII)", Cuadernos de Estudios Gallegos, 66, núm. 132 (2019), págs. 179-203, https://doi.org/10.3989/ceg.2019.132.06 


\title{
HIJOS DEL MAR. LA SIRENA EN EL MITO FUNDACIONAL DE LOS MARIÑO \\ (SIGLOS XIV-XVII)
}

\section{RESUMEN}

En el siguiente artículo se pretende exponer el desarrollo del relato fundacional de los Mariño desde el siglo XIV hasta el siglo XVII determinando las problemáticas historiográficas, iconográficas y textuales sobre la relación de la sirena y su aprovechamiento en el linaje y genealogía de esta familia noble gallega y sus ramas secundarias (Fandiño, Goyanes). Se expondrán las problemáticas de la supervivencia del mito en el tránsito a la Edad Moderna y la crítica textual a la integración de dicho relato dentro de la materia de Melusina al que demostraremos que no pertenece.

PALABRAS ClAVE: Mariño, sirena, genealogía, linaje, nobiliarios, memoria, mito fundacional.

\section{FILLOS DO MAR. A SEREA NO MITO FUNDACIONAL DOS MARIÑO (SÉCULOS XIV-XVII)}

\section{RESUMO}

No seguinte artigo preténdese expoñer o desenvolvemento da relato fundacional dos Mariño dende o século XIV até o século XVII determinando as problemáticas historiográficas, iconográficas e textuais sobre a relación da serea e o seu aproveitamento na liñaxe e xenealoxía desta familia nobre galega e as súas ramificacións secundarias (Fandiño, Goyanes). Expoñeranse as problemáticas da supervivencia do mito no tránsito á Idade Moderna e a crítica textual á integración do dito relato dentro da materia de Melusina ó que demostraremos que non pertence.

Palabras Clave: Mariño, serea, xenealoxía, liñaxe, nobiliarios, memoria, mito fundacional.

\section{CHILDREN OF THE SEA. MERMAIDS IN THE FOUNDATIONAL MYTH OF THE MARIÑOS $\left(14^{\mathrm{TH}}-17^{\mathrm{TH}}\right.$ CENTURIES)}

\begin{abstract}
In this paper we will expose the development of Mariño's foundational story since $14^{\text {th }}$ until $17^{\text {th }}$ centuries concerning historiographical, iconographical and writing problems about the relation of the mermaid with the ancestry and genealogy of this noble galician family and its secondary branches (Fandiño, Goyanes). It will be exposed the problematics of this myth's survivance in transit to the Modern Age and the textual criticism of this story as a Melusine literary matter which it will be prove that does not belong.

KEY WORDS: Mariño, mermaid, genealogy, ancestry, armorials, memory, fundational myth.
\end{abstract}


Recibido/Received: 17/04/2018

Aceptado/Accepted: 31/01/2019

Mortem dabit ipsa voluptas ${ }^{1}$

$\mathrm{E}$

1 objetivo principal de estas páginas ${ }^{2}$ es analizar los significados y variaciones que un relato puede sufrir a lo largo del tiempo debido a la credibilidad del mismo y al enfrentamiento entre diferentes creadores del discurso histórico. A partir de ahí se analizará, por una parte, la nueva contextualización documental del relato fundacional de los Mariño a la luz de documentos inéditos y, por otra, la crítica historiográfica y metodológica al insertar este relato mítico dentro de la tradición de Melusina.

El siguiente apartado seguirá un procedimiento ligado a las tradiciones documentales, la mayor parte de ellas ya conocidas en profundidad, aunque con nuevas aportaciones a partir de documentación primaria que permite un acercamiento renovado a una historia más que conocida en la tradición de la heráldica gallega. Además de exponer la tradición textual coherente entre los siglos XIV y XVII se añadirá una nueva referencia inédita sobre la mitología fundacional de los Mariño en el contexto de la creencia de hombres y mujeres marinos ${ }^{3}$.

\footnotetext{
1 Lema de uno de los Emblemas de Camerarius iluminado con tres sirenas enrosacadas y dos carabelas a los lejos, apud Carlos García Gual, Sirenas. Seducciones y metamorfosis, Madrid, Turner, 2014, pág. 116.

2 Agradezco profundamente las observaciones y referencias pertinentes gracias a los evaluadores anónimos que han ayudado a mejorar y clarificar las tesis del siguiente artículo. Cualquier error o equívoco pertenece a mi autoría.

3 Se ha decidido en el siguiente trabajo que el término mito se adecúa a la naturaleza del relato más que el tratamiento como leyenda, evocación esta de un relato folclórico e insustancial. Frente a ello se justificará que el relato fundacional de los Mariño posee unos mitemas concretos dentro de un mitologema mayor. Para la interpretación de las diferencias y análisis del mito, la leyenda y la historia véanse las obras de referencia de José Carlos Bermejo Barrera, Sueños para unas sombras. Caminos del mito griego, Santiago de Compostela, Enxebrebooks, 2014 y la intervención que durante el curso Retazos da arte, sociedade e cultura na Idade Media: historias, crenzas e mitos ejecutó Isidro García TATO en su conferencia Mito, leyenda e historia inspirado en algunos aspectos de la tradición de Károly Kerényi (1897-1973).
} 


\section{MitologíAS FUNDACIONALES: ENTRE LO FANTÁSTICO Y LO PSEUDO- HISTÓRICO EN LAS MITOLOGÍAS NOBILIARIAS GALLEGAS MEDIEVALES}

¿Por qué radica en los relatos fundacionales nobiliarios la importancia de no pocos linajes? Se puede decir que es debido a la importancia del ídolo de los orígenes tal y como había afirmado F. Simiand ${ }^{4}$, esto es, en el principio de antigüedad correlativo al prestigio del linaje mismo, así como a la pureza y diferenciación de los orígenes. Por lo tanto, la legitimidad nobiliaria se funda no solo bajo el signo de la legalidad regia sino también en el contexto de unos orígenes propios que aportan honra y prestigio a los descendientes. No solo importa el capital simbólico sino las consecuencias que esto implica en cuanto a privilegios sociales y, por supuesto, fiscales ${ }^{5}$. Esta memoria no se podrá discutir de modo que eius inici memoria apellata non existat ${ }^{6}$, aunque como luego se expondrá esto no siempre es así. No obstante, la creación del discurso sobre los orígenes de los nobles no fueron los primeros y tampoco los únicos grupos sociales. Se puede establecer una relación entre tipos de genealogías y los grupos sociales que se ven afectados por las mismas.

Para poder contextualizar correctamente el específico relato fundacional de los Mariño se debe atender una vez más a la importancia del origen, de ese momento fundacional trascendental que diferenciará a un grupo de otro, a una comunidad de su némesis ${ }^{7}$.

Durante la Alta Edad Media (siglos V-XI) la creación de un discurso histórico sobre los orígenes de grupos sociales estuvo bastante ligado a los relatos de prestigio sobre los nuevos pueblos germanos asentados en la Romanitas. Frente a la historia romana con su brillante fundación post-troyana con Eneas, la historiografía altomedieval necesitó explicar, adornar y enardecer la fundación de unos pueblos tenidos por bárbaros. Antes que los orígenes de reyes o nobles, la historiografía

\footnotetext{
4 François Dosse, La historia en migajas: de Annales a la “Nueva Historia”, México D.F., Universidad Iberoamericana, 2006, pág. 27.

5 También se podría afirmar que constituye un marcador sobre las modas y la recepción de legitimaciones simbólicas muchas veces con origen foráneo o que adaptan métodos no autóctonos de auto- representación. Isabel Beceiro Pita, "La legitimación del linaje a través de los ancestros", en Jon Andoni Fernández de Larrea y José Ramon Díaz de Durana (eds.) Memoria e Historia. Utilización política en la Corona de Castilla al final de la Edad Media, Madrid, Sílex, 2010, págs. 77-79.

6 Así lo recoge el Memorial de la Casa de Saavedra en Fernando de SaAvedra Rivadeneyra y Aguiar PARdo de Figueroa, Memorial al Rey N. Señor en que se recopila, adiciona, y representa quanto los Coronistas y autores han escrito y consta por instrumentos del origen y antiguedad, descendencia y sucesión, lustre y servicios de la Casa de Saavedra, Granada, Imprenta Real de Francisco de Ochoa, 1674, pág. 196.

7 Peter G. Bietenholz, "Ad fontes. Renaissance Genealogy and the Myth of the Golden Age”, en Historia and Fabula. Myths and Legends in Historical Thought from Antiquity to the Modern Age, Leiden; New York; Köln, Brill, 1994, págs. 189-220.
} 
medieval necesitó explicar el origen de los pueblos ${ }^{8}$. Más tarde, en relación con las nuevas dinastías regias e imperiales (Capetos, Otónidas, Plantagenet) nacerá a partir del siglo XI la explicación de la fundación, modelo a partir del cual las nacientes casas nobiliarias de los siglos XII-XIII articularán sus orígenes a modo de imitatio $^{9}$.

El relato de los Mariño aparece en el mare magnum que desde el siglo XIV relaciona las casas nobles gallegas a un relato de fundación, en el cual el aspecto ficcional está presente. La diferencia que marcan los Mariño -razón por la cual se ha elegido- es que frente a los relatos de tipo pseudo-histórico basadas en la pérdida de España y de la lucha contra el infiel, los Mariño eligen un origen mítico relacionado con un ser maravilloso, esto es, un tipo de mito escaso junto a las referidas de orígenes suevos, visigodos o incluso romanos que aparecen en otras familias. Este carácter excepcional -un caso único en Galicia y con dos o tres ejemplos en el resto de los reinos ibéricos- posee unas problemáticas propias diferentes de las derivadas de una falsificación del pasado o de la utilización pseudo-histórica ${ }^{10}$.

La mayor parte de los ejemplos de fundaciones prefieren apelar a una memoria pseudo-histórica como los Boán de Temes que creaban una anagnórisis histórica

\footnotetext{
8 En el libro de Magali Coumert, Origines des peuples. Les récits du Haut Moyen Âge occidental (550850), Paris, Institut d'Études Augustiniennes, 2007 (Collection dees Études Augustiniennes, Série Moyen Âge et Temps Modernes-42) se explica la necesidad de las leyendas de los orígenes en los pueblos, de un carácter étnico y diferencial desde muy antiguo como bien muestran las obras de Jordanes, Casiodoro (Getica, Origo Gothica), Paulo Diácono (Origo Genthis Langobardorum) allende las historias más conocidas de los francos y Troya o los visigodos. Sin embargo, es verdad que el relato de los orígenes entre los optimates romanos no era algo nuevo, como la relación entre la Gens Iulia y Venus, desde finales de la República Romana. Para un estudio general sobre los orígenes de los pueblos véase Jon JUARISTI, El bosque originario: genealogías míticas de los pueblos de Europa, Madrid, Taurus, 2000.

9 En el caso franco desde Crodegango se buscó un origen mítico con los troyanos que durante la época de los capetos y de Felipe Augusto se consolidará a pesar de lo cambios de dinastías (merovingios, carolingios, capetos) también llamadas las tres razas. La labor historiográfica de la abadía de Saint-Denis bajo el patronazgo de Luis IX pasará por Felipe Augusto y se consolidará en las manos de Bernard Gui con sus arbores genealogiae que mantiene los orígenes prístinos en Troya. Bernd SCHNEIDMÜLLER, "Constructing the Past by Means of the Present", en Gerhard Althoff, et alii, Medieval concepts of the Past. Ritual, Memory, Historiography, Cambridge; Washington, German Historical Institute; Cambridge University Press, 2002, pág. 170. El caso hispano es más tardío, aunque la vanguardia estuvo en la Marca Hispánica imitando no pocas veces el caso capeto, Eduardo PARDO DE GUEVARA Y VALDÉs, "La materia genealógica en la literatura histórica medieval", en De linajes, parentelas y grupos de poder. Aportaciones a la historia social de la nobleza bajomedieval gallega, Madrid, Fundación Cultural de la Nobleza Española, CSIC, 2012, pág. 21.

${ }^{10}$ El carácter único de la leyenda de los Mariños se enmarca en una pregunta de carácter metodológico. Las escasas menciones de fundaciones sobre ayuntamientos con semi-mujeres se refieren a linajes de las franjas cántabra o atlántica a lo que se une el ser ambas zonas con excelentes nobiliarios lo que podría provocar una distorsión en el análisis, ¿o acaso hay una preferencia por lo fantástico en esas áreas?, BECEIRo PITA, "La legitimación del linaje...", pág. 81.
} 
desde el apóstol Santiago hasta los suevos ${ }^{11}$, los Lobeiras se asentaban en ser hijos de Lupa ${ }^{12}$ mientras que otros como los Losada prefieren dejar el espacio de la memoria apelada en un interregno sin referencias directas a acontecimientos históricos ${ }^{13}$. Son algunos ejemplos de los relatos sobre los orígenes durante los siglos XVI-XVII a casas nobiliarias e hidalgas que ampliaban o inventaban nuevas fundaciones intentando evadir el origen burgués o de caballería villana.

La condición historiográfica de la Edad Media se ve continuamente juzgada bajo el yugo del Renacimiento en relación con la falsificación y manipulación de fuentes escritas, en especial históricas. Sin embargo, y a pesar de los brillantes logros de filólogos del Renacimiento como Poggio Bracciolini o Lorenzo Valla, así como de los métodos de Jean Mabillon durante los siglos XVI-XVII lejos de atenuarse la falsificación e interpolación textual, ésta se dispara con nuevos cronicones, documentos, epigrafía inventada que juega con la Antigüedad y la Edad Media para justificar antigüedad de linajes, de dinastías o de sedes episcopales y dominios territoriales. Los nuevos anticuarios continuaron creando nueva ficción histórica ligada a los nuevos conocimientos de epigrafía o diplomática que facilitaban el engaño.

En la península, y en especial en el ámbito gallego, la aparición de los falsos cronicones ${ }^{14}$ se enmarca en un movimiento europeo dominado por la

\footnotetext{
${ }^{11}$ Estos ben de un regulo chamado Fernando que o postol Sanctiago convertou no pazo de Arcos d'Asua, que he soar destos cabaleyros, e tina moytas terras a mandar. Casou con Marcia Nuniz donde decendeu San Marcelo e Primitiva cibdadaos d'Astasia Cobaria de Galizia, de Ursaria. E deste home decendio Pelayo e Chydasvinto, reys godos e Arria Thodomyro, rey suevo, Jose Antonio Souto CABo (ed.), A História de Don Servando, Santiago de Compostela, Cabido da S.A.M.I. Catedral, Seminario de Estudos Galegos, 2007, pág. 66.

${ }^{12}$ Dicen que desçiende de la casta de Doña Luparia; y ansí como desçendían de gran antigüedad, ansí juntábanse a alta sangre y cada vez más poderosos, Vasco DE APONTE, Recuento de las casas antiguas del Reino de Galicia, introducción y edición crítica por Manuel C. Díaz y Díaz, et al., Santiago de Compostela, Xunta de Galicia, 1986, pág. 101.

${ }^{13}$ En este Reyno, do dizen tierra de Quiroga, avia una montaña muy fértil: la qual dexava de poblarse, a causa que se criaban en ella muy fieros lagartos y estos hazian sus manidas debaxo de unas losas, y dellas salían a matar la gente que por los cominos iva: y assi era inhabitable, hasta que unos mancebos animosos Gallegos de buena casta se dispusieron a andar toda aquella montaña, y matar a quantos lagar pudiessen. Y haziendolo assi, en poco tiempo desarraigaron tan mala simiente, y luego aquella tierra se poblo, que es agora de las mejores deste Reyno. Y por esto traen por armas unas losas, con unos lagartos que asoman por debaxo y destas losas tomaron el nombre de Losadas, que es buena casta y ay dellos muchos en Castilla, que son destos mismos, Bartolomé Sagrario De Molina, Descripción del Reyno de Galicia y de las cosas notables del con las armas y blasones de los linages de Galicia, de donde proceden señaladas Casas en Castilla, 1550, introducción y edición facsímil de José Filgueira Valverde, Santiago de Compostela, Colección de Bibliófilos Gallegos, 1949, fol. 51r.

${ }^{14}$ Uno de los primeros -y también de los mejores- estudios sobre los cronicones en España es de José Godoy Alcántara, Historia crítica de los falsos cronicones, Granada, Universidad de Granada, 1999. Para el caso gallego véase Atanasio LóPEz, "Los falsos cronicones en la historia de Galicia", Nuevos estudios crítico-históricos acerca de Galicia, Madrid, Instituto Padre Sarmiento de Estudios Gallegos CSIC, 1947, págs. 139-173.
} 
impostura ${ }^{15}$. En el caso gallego llama la atención los ya citados Boán con la creación de toda una serie de textos y documentos (Cronicón de D. Servando, Libro Antiguo de Linajes, Historia de Galicia) relacionados también con su tradición universitaria de colegiales de Fonseca ${ }^{16}$ con los que ocultar su pasado de mercaderes.

\section{TRADiciones DOCUMENTALES DEL RELATO FUnDACIONAL DE LOS MARIÑO Y PRECEDENTES: SiRENA O MELUSINA}

El mito fundacional de los Mariño es canónico en cuanto a su planteamiento y motivo principal: el encuentro con una mujer no del todo humana (que proviene del mar ${ }^{17}$ de la cual nace la estirpe. La indigencia de este tema fantástico respecto a la realidad no dejó de ser un tanto paródica y símbolo para algunos eruditos de los excesos fantásticos ${ }^{18}$ por lo que muchas veces antes de llegar a los estudios de crítica literaria o histórica, se recopilaban en antologías folclóricas para la infancia ${ }^{19}$. Para llegar a la versión canónica (la del Livro de Linhagens del Conde de Barcelos $^{20}$ ) se debe exponer antes el excurso de los textos inspiradores o $a$ priori relacionados con el relato de los Mariño.

${ }_{15}$ El caso gallego y en general el ibérico no es una excepción, véase lo que pasa en Alemania en la falsificación de su pasado en el Renacimiento en Christopher Wood, Forgery, Replica, Fiction. Temporalities of German Renaissance Art, Chicago; London, Chicago University Press, 2008, págs. 109-185. Para la crítica de la impostura y la falsificación histórica en Europa entre los siglos XVI-XVII consúltese en Anthony Grafton, Falsarios y criticos. Creatividad e impostura en la tradición occidental, Barcelona, Crítica, 2001, págs. 15-49.

16 Sobre el contexto educativo de los Boán en relación a otros linajes y a su medre, véase Antonio FrAguas Fraguas, Los colegiales de Fonseca, Santiago de Compostela, Instituto Padre Sarmiento, 1958 (Anejos de Cuadernos de Estudios Gallegos, 12), págs. 52-53 y 141-142.

17 Sobre la sirena en el mundo medieval, Jacqueline LeCLerCQ MARx, La Sirène dans la pensé et dans l'art de l'Antiquité et du Moyen Âge. Du mythe païen au symbole chrétien, Bruxelles, Académie Royale de Belgique, 1997, págs. 41-165.

18 Antonio Trueba, Leyendas genealógicas de España, Barcelona, Daniel Cortizo y Comp., 1887, pág. 249. Es esta una obra valiosa por su afán compilatorio más que por su método, pero aun así necesaria para advertir el comienzo del interés de estos relatos, aunque solo fuese folclórico. Agradezco a Eduardo Pardo de Guevara y Valdés su consulta.

19 Son famosas las recopilaciones anglosajonas nacidas al calor de la filología histórica y völkisch de los hermanos Grimm. El encuentro del hombre y la mermaid wife o con otros seres humanoides marinos se encuentra en William W. GibBings, Folk-Lore and Legends. Scotland, London, Constable, 1889, págs. 86-88 y en Thomas Keightley, The Fairy Mithology, illustrative of the Romance and Superstition of various Countries, London, George Bell \& Sons, 1892, págs. 147-155, 169-171 y 480-486.

${ }^{20}$ Do linhagem donde veem os Marinhos, donde o mais longe sabemos; e forom naturaes de Galiza. $O$ primeiro foi ûu cavaleiro boo que houve nome dom Froiam, e era caçador e monteiro. E andando ûu dia em seu cavalo per riba do mar, a seu monte, achou ûa molher marinha jazer dormindo na ribeira. E iam com ele tres escudeiros seus, e ela, quando os sentido, quise-se acolher ao mar, e eles forom tanto empos ela, ata que a filharon, ante que se acolhese ao mar. E despois que a filhou aaqueles que a tomaron fe-a poer em ûa besta, e levou-a pera sa casa. E ela era mui fermosa, e el fe-a bautizar, que lhe nom caia tanto nome nem ûu como Marinha, porque saira do mar; e assi lhe pôs nome, e chamarom-lhe dona Marinha. E houve dela seus filos, dos quaes houve ûu que houve nome Joham Froiaz Marinho. E esta 
Desde la creación de la moderna teoría literaria en el siglo XIX, el mito de Melusina ha sido objeto de un estudio minucioso sobre todo en lo referente a las comparativas con un motivo -el de la sirena y el hombre- que llega hasta Japón con el mito de Hohademi al casarse con la hija del mar. La centralidad de la mujer en estos mitos inspiró las herencias de Johan J. Bachofen por la búsqueda de los orígenes de la transición entre el matriarcado y el patriarcado ${ }^{21}$ leyendo estos mitos como herederos de la transición.

En el mito francés de Melusina una mujer con pie de cabra o que muta en dragón o serpiente es desposada con un caballero al cual pone algunas condiciones para la relación a cambio de prosperidad, fecundidad y poder de la casa. La transgresión de la norma estipulada por la mujer (no observar cómo se baña, no visitarla los sábados, entre otras) provoca su huida al conocer el marido la forma monstruosa de su cónyuge. La principal versión de esta obra de origen francés se remonta a finales del siglo XIV relacionada con la Casa de Lusignan ${ }^{22}$ y tiene por objeto el engrandecimiento o diferenciación de esta casa nobiliaria con origen en Poitou. La relación de Berry y este mito se constata en tanto que los dominios franceses de esta familia (los Lusignan) pasaron a dominio real y luego al apanage de los Berry ${ }^{23}$.

Al interrogante que encabeza este apartado corresponde un escepticismo en cuanto a la relación que Melusina tiene con el mito de los Mariño, no con otros del ámbito ibérico (como el de la fundación de la casa de Haro). Si se siguen los

dona Marinha nom falava nemigalha. Dom Froiam amava-a muito e nunca lhe tantas cousas pode fazer que a podesse fazer falar. E û dia mandou fazer mui gram fugeira em seu paaço, e elea viinha de fora, e trazia aquele seu filho consigo, que amava tanto como seu coraçom. E dom Froia foi filhar aquele filho seu e dela, e fez que o quería enviar ao fogo. E ela, com raiva do filho, esforçou de braadar, e com o braado deitou pela boca ûa peça de carne, e dali adiante falou. E dom Froia recebeo-a por molher $e$ casou com el. Se utiliza la edición de referencia Livro de linhagens do Conde Dom Pedro, edición crítica de José Mattoso, Lisboa, Academia das Ciências, 1980 (Portugaliae Monumenta historica: a saecvlo octavo post Christvm vsque ad qvintvmdecimvn ivssv academiae scietiarivm olisiponensis, Nova Série, vol. II/2), págs. 169-170. A partir de ahora abreviado como $L L$.

${ }^{21}$ Véase una de las primeras obras dedicadas a los orígenes del tema en Josef KoHLER, Der Ursprung der Melusinensage, Leipzig, E. Pfeiffer, 1895, pág. 21, así como las críticas que vierte N. VIESIELOVSKII sobre el carácter totémico en Alexander Nikolayevich ViesielovskiI, "Poética de los Argumentos", en Poética histórica, Madrid, Akal, 2014, págs. 632-633. Sobre la problemática del matriarcado antes y después de Johan Jakob Bachofen consúltese en Mar Llinares García, Los lenguajes del silencio. Arqueologías de la religión, Madrid, Akal, 2012, págs. 37-75. En general sobre la sirena a lo largo de la tradición occidental medieval véase, García GuAL, Sirenas..., págs. 81-109.

22 Precedentes del relato como en Gautier Map (De nugis curialium) de fines del s. XII o los Otia Imperialia de Gervais de Tilvury de principios del s. XIII, pero las principales obras fueron escritas por Jean d'Arras por encargo del duque Jean de Berry y su hermana Marie, duquesa de Bar, entre 1387 y 1394. En los títulos de la obra ya se confunde y relaciona la casa de Lusignan con lo que será las Melusinensagen. Enmanuel Le Roy Ladurie y Jacques Le GofF, "Mélusine maternelle et défricheuse", Annales. Économies, Sociétés, Civilisations, 26, 3-4, (1971), págs. 587-588 y 590.

23 Le Roy Ladurie, Le Goff, “Mélusine maternelle...”, pág. 590. 
parámetros que utiliza Le Goff a partir de la morfología del cuento de Vladimir Propp las coincidencias se debilitan ya que de los cuatro parámetros solo coincide $u_{n o}{ }^{24}$. Otras discordancias son evidentes, en especial el conocimiento o no por parte del caballero de la semi-humanidad de la mujer. En el relato de los Mariño desde el principio conoce la forma de sirena (molher marinha) mientras que en el relato de Melusina la almendra narratológica es el descubrimiento/desvelamiento por parte del caballero de que la mujer no es como creía sino una mujer-serpiente o mujer-dragón. La forma del relato y hasta su temática divergen de una forma sobresaliente por lo que la relación es poco útil25, aun estando constreñidos por la brevedad del relato del Conde de Barcelos.

En la primera mitad del siglo XIV uno de los nueve hijos bastardos del rey Don Dinís de Portugal, Don Pedro Alfonso, Conde de Barcelos, creó uno de los nobiliarios más completos del ámbito ibérico, en especial de los reinos de Castilla y Portugal. Su exhaustiva relación de casamientos, descendencia y antepasados en numerosas familias, así como la introducción de determinados pasajes narrativos sobre orígenes de familias y casas reales como los Trastámara ${ }^{26}$ hicieron de este Livro uno de los más citados y copiados hasta la primera Edad Moderna en el ámbito genealógico. La redacción del Livro se fecha alrededor del 1340-1344 con algunas refundiciones ya en $1360^{27}$.

\footnotetext{
${ }^{24}$ Los parámetros de Vladimir Propp son: 1-el héroe sale a cazar/se aleja de casa, 2-se le impone una prohibición al héroe, 3-la prohibición es transgredida, 4-el antagonista intenta obtener información de la desaparición de Melusina. Solo el parámetro 1 coincide con la mito de Mariña. Ibíd., pág. 597. Baroja ofrece ejemplos alternativos de uniones con mujeres sobrenaturales con alguna deformación o simbología teratológica, muchas veces referida a elementos acuáticos fluviales o marítimos en la que inscribe a Melusina. Pero si bien la condición ambiental acuática o de deformidad se cumple, el rasgo de la condición que no se puede transgredir por parte del hombre no existe en el caso de los Mariño, Julio CARo BAROJA, De los arquetipos y las leyendas, Madrid, Istmo, 1991 pág. 148.

${ }^{25}$ En el análisis de María del Pilar Paredes Mirás no se aclaran las divergencias entre el relato melusiniano y el de la sirena de los Mariño y se cita una versión modificada del s. XVII del Nobiliario que más que explicar las diferencias, ejemplifica el fin del mito de la mujer biforme en el Barroco. María del Pilar PARedes Mirás, Mentalidade nobiliaria e nobreza galega: Ideal e realidade na Baixa Idade Media, Noia, Toxosoutos, 2002, pág. 122. François Delpech ya demostró que las relaciones melusinianas eran superficiales y discordantes con el relato galaico ya que "dans les légendes mélusiniennes elle détermine et accompagne une séparation, consacre une irreductible incompatibilité, et introduit une distorsion irrémeédiable à l'intérieur du lignage", François DelPeCH, "Legende de Dona Marinha: Mythologie et genealogie”, Cuadernos de Estudios Gallegos, LV, 121 (2008), pág. 419.

${ }_{26}$ Al igual que el primero de los Mariño (que no su fundador), el primer antepasado de los Trastámara (el conde de origen godo Monido) llegó a tierras gallegas (Cabo Prior, Coruña) por mar desde Roma. Véase sobre la función de esta genealogía alternativa a la asturiana de Alfonso II en Luis Krus, "As origens lendárias dos Condes de Trastâmara", Penélope. Fazer e desfazer a História, 8, (1998), págs. 43-49.

${ }^{27}$ La iniciativa del Conde de Barcelos se enmarca en un proyecto heredado de la historiografía alfonsí por una recopilación de materia poética (Livro das Cantigas), histórica (Crónica Geral de Espanha de 1344) amén de la propia genealógica del Livro de Linhagens, PARDO DE GUEVARA Y VALDÉs, "La materia genealógica en la literatura histórica medieval...", págs. 24-25 y Santiago GuTIÉRREz GARCíA y Pilar LORENZO Gradín, A literatura artúrica en Galicia e Portugal na Idade Media, Santiago de Compostela, Universidade de Santiago de Compostela, 2001, págs. 47-48.
} 
Al principio del título LXXIII del Livro das Linhagens ${ }^{28}$ aparece la primera versión del relato fundacional de los Mariño de la cual nacerán las modificaciones y versiones hasta el siglo XVII. La autoría de esta se tiene atribuido a Pai Gomez Charinho (ca.1248-1295), el poeta del "mar maior"29 aunque esta autoría sigue siendo dudosa. Al parecer este trovador pertenecería también a la familia de los Mariño ya que Charinho no sería más que una lectura diferente del apellido Marinho cuyas primeras menciones aparecen en 1245 como al llamar a Gonzalo Eanes dictus Marinus en la comarca compostelana ${ }^{30}$.

Lo que sí se debe investigar es la inclusión de dos relatos de tipo melusiniano en el $L L$, la de los Mariño y los Haro, sobre todo estos últimos. El relato fundacional de los Haro es, como ya se ha afirmado (ver supra), una historia con una evidente relación el mito melusiniano ${ }^{31}$ en la Dama de Pie de Cabra, un título inspirado en la deformidad que sufre en el mito esta mujer. En el relato, tras explicar la versión de los orígenes de la independencia de Vizcaya por el caudillo inglés Froom, se narra cómo Diego López -biznieto del primer señor de Vizcaya- se ve atraído en el bosque por la voz de una mujer con un pie de cabra. Como obliga el relato, inmediatamente Diego López le pide matrimonio y ella acepta a condición de que no se santigüe su futuro marido. Tras tener dos hijos -niño y niña- la observación por Diego de la muerte de un alano por un ave menor provoca que se santigüe, la transgresión de la prohibición de la mujer y la huida de esta a las montañas con su hija, dejando al hijo varón con el padre ${ }^{32}$. La narración de esta historia tiene similitudes y diferencias con la de los Mariño y son los dos únicos ejemplos de este tipo

\footnotetext{
${ }^{28}$ Livro de Linhagens do Conde Dom Pedro..., págs. 169-170.

29 Esta es la hipótesis que defiende Luis Krus, Passado, Memória e Poder na Sociedade Medieval Portuguesa. Estudos, Redondo, Patrimonia Historica, 1994, págs. 178-179. Sobre Pai Gomez Charinho, António Rosende de Oliveira, Trobadores e Xograres. Contexto histórico, Vigo, Xerais, 1995, págs. 162163 y el estudio y edición de sus obras de Armando Cotarelo Valledor, Cancioneiro de Payo Gómez Charinho almirante y poeta (siglo XIII), Santiago de Compostela, Xunta de Galicia, 1984.

${ }^{30}$ Así lo parecen confirmar documentos del s. XIV como el que el 1 de diciembre de 1362 cede a Juan Mariño unas feligresías vacantes por parte del arzobispo Suero Gómez de Toledo tras la renuncia del hermano del primero, Pai Gómez Charinho. Marta González VÁzQuez, El arzobispo de Santiago: una instancia de poder en la Edad Media (1150-1400), Sada, Seminario de Estudos Galegos, Ediciós do Castro, 1996, págs. 198-199.

31 Sobre el mito melusiniano de los Haro véase la tesis doctoral de Jose RAmón Prieto, Las leyendas de los Señores de Vizcaya y la tradición melusiniana, Madrid, Fundación Ramón Menéndez Pidal; UAM; Universidad del País Vasco, 1995 y Luis Krus, "Uma variante peninsular do mito de Melusina: a origem dos Haros no Livro de Linhagens do conde de Barcelos", en A construçâo do passado medieval. Textos inéditos e publicados, Lisboa, Instituto de Estudos Medievais, 2010, págs. 151-171. Véase también la traducción y nueva edición en Luis KRUs, "Una variante peninsular del mito de Melusina: el origen de los Haro en el Livro de Linhagens del Conde de Barcelos", en Antonio Dacosta, Jose Ramón Prieto Lasa y José Ramón Díaz de Durana (eds.) La conciencia de los antepasados: la construcción de la memoria de la nobleza en la Baja Edad Media, Madrid, Marcial Pons, 2014, págs. 17-43.

${ }^{32}$ LL, IX en Livro de linhagens..., págs. 138-141.
} 
ofrecidos en el $L L$. La convivencia de estos dos mitos remarca también sus amplias diferencias al ser la de Dona Mariña según Paredes Mirás una versión muy cristianizada donde la mujer no huye dejando la descendencia al hombre ni rechaza la religión ${ }^{33}$. El problema de esta relación es que, si bien es útil la comparación con el relato de los Haro, el relato de los Mariño nace en un contexto discursivo atlántico que poco tiene que ver con Melusina más allá de la deformación corporal de esas hadas. Otro problema es explicar por qué dentro del $L L$ aparecen dos versiones del mito melusiano: uno, muy cristianizado (Mariños) y otro que conserva las características más salvajes de la mujer (Haro de Vizcaya). En ambos casos el relato es una lucha por el carácter civilizatorio $^{34}$ (el habla, lo teratológico, la capacidad de engendrar y la institución del matrimonio y linaje) si bien solo en los Mariño parece ser próspera esa fundación ya que pertenecen a las Melusinensagen ${ }^{35}$.

\section{PROFANAR A LA SIRENA: TRADUCCIONES, NUEVAS VERSIONES Y MITOS ALTERNATIVOS AL LIVRO DAS LINHAGENS (SIGLOS XVI-XVII)}

El cambio de paradigma discursivo inutiliza las versiones de la sirena con el caballero por parte de algunos editores y copistas buscando una similitud que no soporta el carácter maravilloso ${ }^{36}$. No es una rotura con la tradición medieval, sino que decide ganar el favor del nuevo pacto de coherencia, creando una versión diferente castigando a la anterior, pero sin inutilizarla completamente. Se deslegitima el mito fundacional pero no el hecho en sí de la fundación del linaje. Esta maleabilidad del relato posee el carácter de obra abierta del $L L$ que ya había sido promocionado por el propio Don Pedro ${ }^{37}$.

En una de las traducciones al castellano del siglo XVII del $L L$ se puede leer en su título completo: Nobiliario del Conde de Barcelos, Don Pedro, Hijo del

\footnotetext{
${ }^{33}$ Maria del Pilar PAredes Mirás, "El simbolismo del hada en la sociedad caballeresca bajomedieval”, en Ana Isabel Jiménez Cerrada y José María Arribas Lorenzo (eds.), De los símbolos al orden simbólico femenino (ss. IV-XVII), Madrid, Asociación Cultural Al-Mudayna, 1998, pág. 62.

34 Beceiro Pita, "La legitimación del linaje...”, pág. 93.

35 Véase nota 23.

${ }^{36}$ Es una profanación en cuanto lo hace profano, y sacrificable en el sentido de "maldito, excluído de la comunidad", en este caso de la comunidad discursiva. Giogio Agamben, "Elogio de la profanación", en Profanaciones, Buenos Aires, Adriana Hidalgo, 2013, pág. 102.

37 e rogo a aquelles que depos de min veerem e vontade houverem de saber os linhagêes, que acrecenten em estes titolos deste livro, "Prólogo", LL apud PARDo DE Guevara Y VAldés, "La materia genealógica en la literatura histórica medieval...”, pág. 26. Esta noción del $L L$ como obra modificable recuerda mucho a lo que Umberto Eco dio en llamar la "obra abierta": "a) el autor da comienzo a un objeto determinado y definido, con una intención concreta, aspirando a un deleite que la reinterprete tal como el autor la ha pensado y querido; b) sin embargo el objeto es gustado por una pluralidad de consumidores, cada uno de los cuales llevará el acto de gustar a sus propias características psicológicas y modelos culturales" Umberto Eco, "El problema de la obra abierta", en La definición del arte, Barcelona, Planeta, 1985, pág. 157.
} 
Rey Don Dionís de Portugal. Traduzido castigado y con nuevas ilustraciones de varias notas. Evidentemente se debe prestar atención a esa palabra "castigado" que remite a un tipo censura en donde se producen fenómenos que afectan al relato de los Mariño como el siguiente:
Mariños, han quitado deste Nobiliario el cuento que trae el Conde Don Pedro desta familia: mi opinión es que esta señora Mariño era hija de la Casa i solar de las Mariñas en Galicia (...) por comprensión del vulgo vino a aparecer increíble y a quitarse de este nobiliario ${ }^{38}$

Ya con anterioridad la versión del $L L$ no era aceptada por maravillosa y por increíble designándola como cuento, esto es, fábula. Así se encuentra en Sagrario de Molina ${ }^{39}$ y Felipe de la Gándara ${ }^{40}$. Si castigar, censurar o desprestigiar son formas de saltarse la memoria del mito existe otra incluso más refinada, la elipsis o simplemente crear una tradición textual paralela que nada tenga que ver con la tradición desde el Conde de Barcelos, este es el caso de los Boán en su famoso

\footnotetext{
38 Manuel de Faria I Sousa, Nobiliario del Conde de Barcelos Don Pedro hijo del rey Don Dionis de Portugal, Madrid, Alonso de Paredes, 1646, pág. 607. Véase lo mismo en Paredes Mirás, Mentalidade nobiliaria..., pág. 122 .

${ }^{39}$ Los Mariños quieren algunos decir que vienen de una mujer criada en las aguas de la mar, que era de hermoso rostro; y que un hidalgo deste Reyno la ovo en su poder, hasta que quitadas las escamas, que como pesce traía, ovo della generación: lo qual es un simple cuento; porque la verdad es que vienen de un estrangero que vino por la mar y se caso en este Reyno con una noble mujer, de los quales vienen estos Mariños: y llamanse assi, por aver venido por la mar: Traen las armas unas ondas azules, SAGRARIO DE Molina, Descripción del Reyno de Galicia, fol. 51v. Véase para este apartado sobre Sagrario de Molina, los Boán y el contexto historiográfico galaico entre el s. XVI y comienzos del s. XVII en Ofelia REY Castelao, “As Historias de Galicia na Idade Moderna", en Isidro Dubert (ed.) Historia das historias de Galicia, Vigo, Xerais, 2016, págs. 241-270. Las nuevas motivaciones de la historiografía propiamente gallega posiblemente nacen en este s. XVI y se definen por unos objetivos concretos de instrumentum honoris en la antigüedad eclesiástica y nobiliaria del reino gallego frente a Castilla, Xose Ramón BARREIRo FERnÁNDEZ, “A Historia da historia. Aproximación a unha historia galega: de Murguía a Risco", en Justo G. Beramendi, Galicia e a historiografia, Santiago de Compostela, Tórculo, 1993, págs. 183-210. Queda por consultar aún la obra genealógica de Rodrigo DE CASTRO, Tálamo de Galicia en que se refieren las casas solariegas, su antigüedad, calidad y descendencias desde su principio, BNE, ms. 11763 en el cual se refiere otra versión de alrededor del 1650 sobre los Mariño y su relato fundacional.

${ }^{40}$ Traen por armas los Mariño quatro ondas açules en campo de plata, i por timbre del escudo una Sirena. No nombran los autores al Cavallero; pero según mi cuenta presumo era Paio Annes Mariño, quien casò con D. Maior Turrichao, ija de Fernández Turrichao, i de Teresa Pérez Bello, i dizen algunos que se allaron después ser una sangre con los Vargas, i Mariños, Felipe DE LA Gándara, Nobiliario armas y triunfos de Galicia, hechos heroicos de sus hijos y elogios de su nobleza, y de la mayor de España y Europa, Lib. III, Cap. VIII, Madrid, Julián Paredes, 1677, pág. 349. También en el Nobiliario de Gratia Dei se hace mención a que el relato de la mujer marina es, despectivamente, un cuento, y que en realidad se llaman Marinos por haber venido de un varón que por mar vino, Pedro de Gracia DeI, Nobiliario de Gratia Dei, BNE, ms. 18053, fol. 70r.
} 
Cronicón de Don Servando ${ }^{41}$ y en otras obras ${ }^{42}$ de su mismo "taller" historiográfico. En el Recuento de Vasco de Aponte si bien no trata los Mariño como Casa en ningún momento, si cita otras laterales a esta como los Lobeira y sin mencionar nunca al mito de la sirena.

Todas estas referencias de obras históricas, genealógicas y alguna falsificación e impostura con el pasado como los Boán alertan sobre un cambio en la sensibilidad literaria y social. Es lo que -utilizando la nomenclatura de Luís Krus ${ }^{43}$ - se llama la muerte (simbólica) del hada ya que ésta puede venir bien por la negación de la mujer como sirena o bien, como se ha expuesto, mediante la creación de relatos alternativos que superen la conocida utilizando el recurso a una pseudo-historia de la edad antigua, determinada temporalmente y localizada en una edad heroica donde se mezclan santos, suevos y godos además del motto, la guerra contra el infiel. ¿Se puede afirmar, expuesto este giro interpretativo que la sirena como símbolo genealógico pereció con la Modernidad? No del todo y su nueva vida será a través de la imagen y de otras tradiciones -sobre todo manuscritas y artísticas- de la Modernidad.

La memoria del mito solo se hace realidad cuando el contexto que lo ha creado se ha roto o desaparecido y por tanto la calidad epifánica de lo maravilloso. Frente a la condena del cuento medieval aparecen otras contextualizaciones cuyo principal recurso no será la naturalización y humanización de la sirena, sino la posibilidad de que así sea ${ }^{44}$.

${ }^{41}$ Estos decende de Cayo Mario, gobernador de Galicia. Ten seu soar na isla de Salvora e terra de Gojas. Estos se juntaron òs Vargas e Ribeyras. Tran por divisa unhas ondas azuladas en campo dourado, Souto Cabo, A História de Don Servando..., pág. 77.

${ }^{42}$ La referencia es a un manuscrito inédito posiblemente del siglo XVI escrito por Juan Fernández de Boan y su sobrino Juan Fernández de Boán y Araújo. En el manuscrito se recoge en la primera parte un libro de linajes que se remonta hasta la tardorromanidad escrito en un tipo de letra neogótica, intencionadamente arcaizante y en gallego así como un memorial de los Fernández de Temes y Boán (Antiquissimo y muy autentico) en la segunda parte: Este linaje he moito antigo de homes fijosdalgo decenden de Caio Mario, cabaleiro romano gobernador de Galiza, que era de los suevos e germanos. Era parente de Lucio Catel e Pedre de Sancta Marina. Era descendente de Ludicio [sic] e de seu fillo Caio Mario e en tempo do emperador Filipo primeiro foe de Galiza un valeroso capitán chamado Marino e, vaijando contra Roma os godos, foe por capitan general contra iles e os soldados do exercito romano ho alçaron por enperador e logo ho fez matar Decio [?] español galego da terra e quedaron os Marino fillos en Galicia no seu soar e pazo na illa de Salvora e terra de Bojas [sic]. Estos se juntaron os Vargas e Riveiras por casamentos e Chucurranos. Son sua divisa unas ondas azuladas en canpo dourado. E tanven se juntaron os Sobrados e Fernandez de Temes e Boan, LIBRo ANTIGUO DE LOS LINAJES DE GALICIA, BNE, ms.6329, fol.35v (documento inédito). Agradezco a Isidro García Tato (CSIC-IEGPS) la ayuda en la transcripción de este documento.

${ }^{43}$ El autor portugués se refería en detalle al caso de la Dama de Pie de Cabra de los Haro de Vizcaya y por amplitud a esa transición dolorosa hacia la incredulidad moderna de estas genealogías. Luis KRUS, "La muerte de las hadas: la leyenda genealógica de la dama de pie de cabra", en Dacosta, Prieto Lasa y Díaz de Durana, La conciencia de los antepasados..., págs. 43-87.

${ }_{44}$ Observaciones de autores del siglo XVII intentaban justificar la credulidad medieval de formas curiosas, incluso con la fiscalidad: Y que aya dichos Tritones (que se llaman hombres marinos) no es materia 
Diego Hernández de Mendoza es uno de los genealogistas y tratadistas de heráldica más respetados en el siglo XVI para Castilla ${ }^{45}$. Poco se sabe de su vida y su principal obra -conocida muchas veces como Libro de los linajes más principales de España ${ }^{46}$, Armorial o Nobiliario- no se publicó impresa hasta fechas muy recientes, difundiéndose a través de numerosas copias manuscritas hasta bien entrado el siglo XVIII. A priori en este tratadista de la época de los Reyes Católicos no se encontraría nada más respecto a los Mariño que una repetición de lo que ya dice el Conde de Barcelos, o en su caso una versión humanizando a la sirena.

En realidad, no importa tanto el armorial en sí como las copias que nacieron de él introduciendo variaciones en los apógrafos y copias ${ }^{47}$. En una de las copias manuscritas conservadas en la BNE hay tres que deberían llamar especialmente la atención al aparecer información sobre el relato de los Mariño que contextualiza el mito de la sirena.

En el manuscrito 9330 (ca. 1600-1650) de la BNE aparte del relato de la sirena aparece añadido por parte del copista la anécdota al descubrimiento de un hombre marino, esto es, un tritón u hombre salvaje marino ${ }^{48}$ (Fig. 2). La historia del

de duda, como consta de los Archivos de Portugal donde se movió pleito antiguamente entre el Rey y el gran Maestre de Santiago, sobre a quien pertenecia el tributo de los Tritones y Sirenas de la mar y se sentenció que el tributo de las Sirenas tocava al Rey y el de los Tritones al gran Maestre. Antonio de FuentelaPeÑa, El ente dilucidado. Discurso único novíssimo que muestra que ay la naturaleza animales irracionales invisibles y quales sean, Madrid, Imprenta Real, 1676, pág. 187.

${ }^{45}$ La obra de Hernández de Mendoza no se limita a la Península Ibérica a pesar de que el grueso de los linajes que expone sean castellanos (200) sino que recopila tradiciones del resto de Europa inspirándose en armoriales anglo-franceses del siglo XIII. Isabel BECEIRO PITA, "La memoria y el discurso de la nobleza en los relatos genealógicos castellanos (1370-1540)", en Dacosta, Prieto Lasa y Díaz de Durana, La conciencia de los antepasados...,pág. 129. La edición impresa de la obra de Hernández de Mendoza se inserta en un artículo de Miguel Ángel Ladero Quesada, ““"No curemos de linaje ni hazanas viejas...”: Diego Hernandez de Mendoza y su visión hidalga de Castilla en tiempo de los Reyes Catolicos", Boletín de la Real Academia de la historia, 198, 2 (2001), págs. 205-314 (el texto de Mendoza empieza en la página 239).

46 Véase el estudio de referencia de esta obra y autor en Pedro Blas VAlverde Ogallar, Manuscritos y heráldica en el tránsito a la modernidad: el libro de armería de Diego Hernández de Mendoza, Madrid, Universidad Complutense, 2002.

${ }^{47}$ Como nos informa Ambrosio de Morales, el triunfo de la obra fue inmediato: En tiempo de los Reyes Católicos don Fernando y doña Ysabel escrivió Diego Hernández de Mendoza, vezino de Madrid, su Nobiliario de quasi todos los notables linajes de Castilla. Anda este libro escrito de mano en manos de muchos, aunque saben pocos quien fue el autor, y selo yo por aver visto su mismo original que él escrivió, Ambrosio de Morales, Discurso de la verdadera descendencia del glorioso Doctor Santo Domingo, y como tuvo su origen la ilustrísima casa de Guzmán, Córdoba, 1586, f. 334 apud Valverde Ogallar, Manuscritos y heráldica en el tránsito a la modernidad..., pág. 491.

${ }^{48}$ Ay deste linaje hera el que tubo la contienda que digimos con Garci Perez de Bargas sobre las hondas, bien parece esto cosa de Patraña pues digo que siendo arzobispo de Sanctiago Don Gaspar de Zúñiga $i$ Abellaneda, un año, o dos antes, o después de la quema de Caçalla, siendo yo de siete o ocho años, hubo una gran tormenta en la mar, y un dia después que vino bonanza, salieron los cercos al mar, a pescar la sardina que con tormenta estava en la Ría, o brazo de mar, y hechadas las redes tomaron en ellas un 


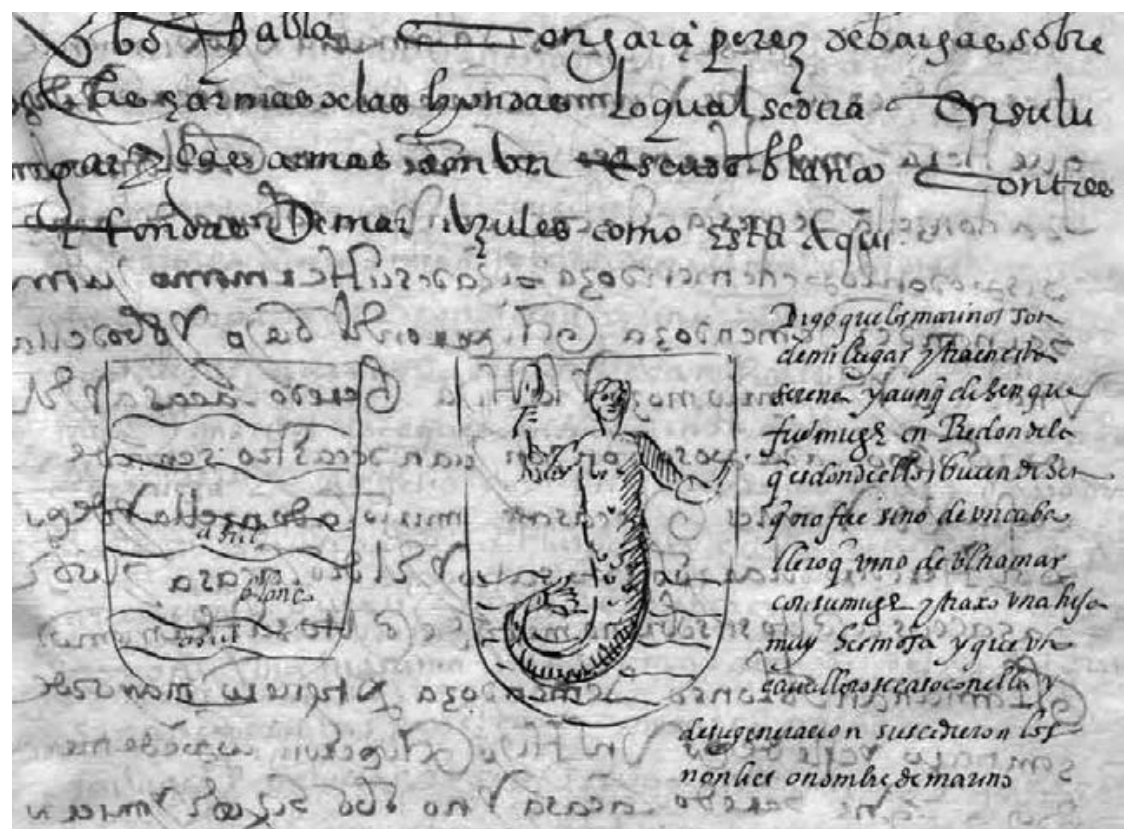

Fig. 1. Representación heráldica del escudo de los Mariño. Imagen tomada de Diego Hernández de Mendoza, Memoriales de linajes, 1540, Madrid, BNE, ms.11661, fol.59r, disponible en

$<$ http://bdh-rd.bne.es/viewer.vm?id=0000192341\&page $=1>$ [consulta: 10-10-2017].

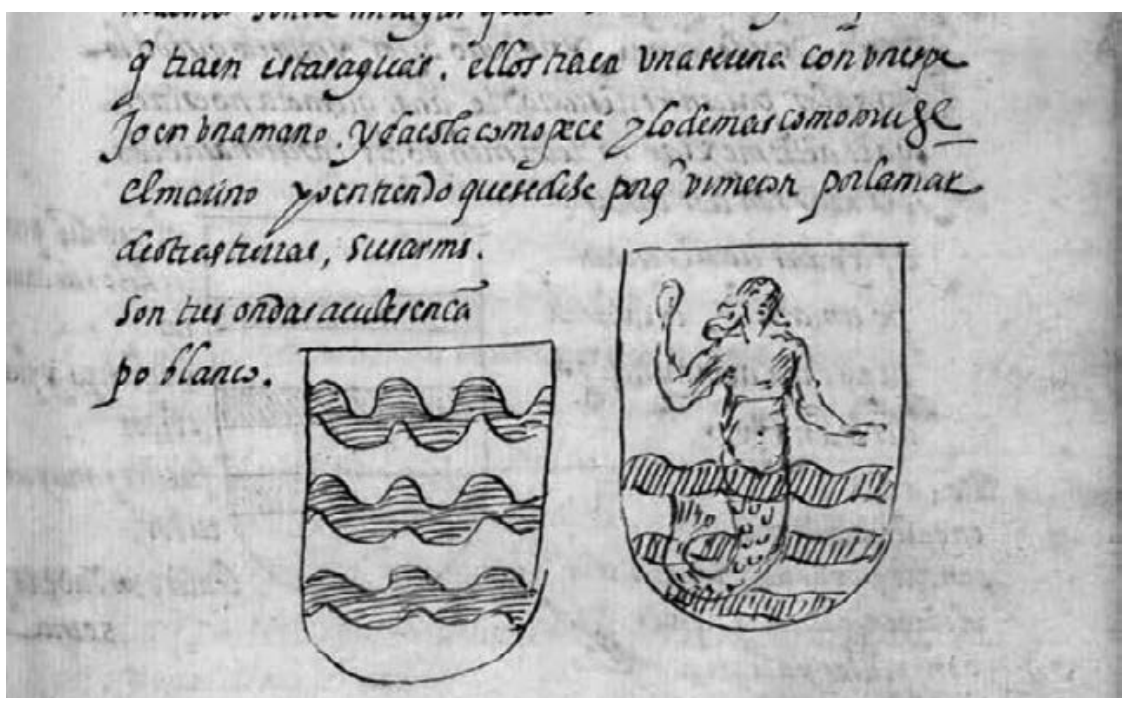

Fig. 2. Representación heráldica de los Mariño. Imagen tomada de Diego Hernández de Mendoza, (ca. 1600-1650), BNE, Ms. 9330, fol. 86r,<http://bdh-rd.bne.es/viewer.vm?id=0000100372\&page $=1>$ [consulta: $10 / 10 / 2017]$. 
hombre marino capturado de las aguas solo aparece en estos dos manuscritos en uno de los cuales -el más antiguo- posiblemente se pueda deducir quien es el autor: Domingo Díaz ${ }^{49}$ de Redondela ${ }^{50}$, al sur de Galicia. A él se refiere también las indicaciones temporales que da de su vida ("siendo yo de siete u ocho años" / "después de la quema de Caçalla" / "siendo arzobispo de Santiago Don Gaspar de Zúñiga y Abellaneda" ${ }^{51}$ ), situando la redacción del manuscrito entre finales del siglo XVI y principios del siglo XVII siendo incompatible con la cronología de Hernández de Mendoza, muerto a principios del siglo XVI.

Por esa misma época de principios del siglo XVII otras fuentes gallegas como el Memorial de Jerónimo del Hoyo relataban, en medio de un relato de las relaciones de rentas, parroquias e iglesias, la aparición de hombres marinos en A Coruña $^{52}$. Ambos relatos, el de Domingo Díaz dentro del libro de Hernández de Mendoza y el de Jerónimo del Hoyo son contemporáneos y tienen el rasgo de que sus historias no se remiten -según ellos- a obras o autores anteriores sino a vivencias de historia oral. En este punto se debe advertir que, según el copista de Mendoza, el mito de la sirena podría ser posible en tanto que el experimentó cómo su familia relataba un acontecimiento similar, pero con el hallazgo de un hombre marino: ¿es de verdad una vivencia y experiencia personal o está más cerca de ser una tradición?

En la primera década del siglo XIII el abad cisterciense Rodolfo de Coggeshall (m. ca.1228) decidió añadir a su Chronicon Anglicanum -centrado en el desarrollo

hombre marino con barvas, i cabello, manos como las nuestras, excepto que no tenía pies, i lo pusieron en una pipa de agua salada para embiarle al Arzobispo de Sanctiago, i me acuerdo contar en casa de mis tíos, del, y decían que no ablava, Diego Hernández de Mendoza, Nobiliario Antiguo, BNE, ms. 9330, fol. 85v-86r. Hay copia manuscrita del siglo XVIII de este mismo pasaje en HernándeZ De MendozA, Tratado de blasones, BNE, ms. 10665, págs. 256-257.

49 La localización de este nombre con grandes caracteres a modo de firma aislada del cuerpo de texto al que se refiere podría indicar la autoría del copista que introdujo esta historia. Hernández de MendozA, Nobiliario Antiguo, BNE, ms. 9330, fol. 249v. En la BNE, ms.11661, fol.59r se observa una nota marginal de mano posiblemente del mismo copista que el ms. 9330 debido al idéntico tipo de letra y a la información que aporta: Digo que los Marinos son de mi lugar y traen esta serena y aunque deben que fue muger en Redondela (...) Fue sino un caballero que vino de ultramar con su muger y traxo una hija muy hermosa y que un cavallero se caso con ella y de su generacion suscedieron los nonbres o nombre de marino (documento inédito) (Fig. 1).

${ }^{50}$ Estos Mariños son de mi lugar, que es Redondela, Hernández de Mendoza, Nobiliario Antiguo, BNE, ms.9330, fol. 86r.

${ }^{51}$ Con la "quema de Caçalla" se refiere al auto de Fe que llevó en el año de 1559 en Valladolid a la ejecución (entre otros) en la hoguera del Doctor Cazalla, antiguo capellán de Carlos V, por sospechas de luteranismo, Bartolomé Bennasar, et al., "La época de los disturbios", en Historia Moderna, Madrid, Akal, 1991, pág. 309.

${ }^{52}$ Algunas veces se an visto en esta playa algunos pescados de la misma figura que onbres y en todo les paresçen salvo que tienen las manos y pies un poco torçidos por rraçon de andar siempre nadando como las rranas, Jerónimo Del Hoyo, Memorias del Arzobispado de Santiago. Reproducción facsimilar, Santiago de Compostela, Consorcio de Santiago, Universidade de Santiago de Compostela, 2016, fol. $230 v-231 r$. 
de la Orden del Císter entre Francia e Inglaterra entre 1166-1223- algunos pasajes con noticias extrañas, entre ellos el de la aparición de los niños verdes y el que incumbe, la historia del hombre marino capturado ${ }^{53}$. Las similitudes con el copista de Mendoza son llamativas: en ambos relatos se refiere la noticia de la captura de un hombre marino, su encierro, su tortura o exposición ante el señor de la tierra para que hable y la huida posterior del hombre salvaje marino. En el caso de Rodolfo de Coggeshall la historia se desarrolla en el castillo de Orford cuando se tortura al hombre marino para que hable. A su vez Rodolfo informa de que "sicut de quodam legitur in vita beati Audoeni" 54 , esto es, ya encuentra a su vez un precedente ${ }^{55}$ en la Vita de este santo escrita en los siglos IX-XI. El relato de Roberto de Coggeshall también parece similar a las primeras referencias sobre el llamado Pesce Nicolao cuyas primeras referencias son del siglo XII en Inglaterra y también Sicilia ${ }^{56}$.

Tras exponer los antecedentes se debe entonces encuadrar el relato que aparece en el manuscrito 9330 de la BNE en un conjunto de mitos de ámbito atlántico donde la tradición de los Mariño y la sirena se engloba ${ }^{57}$ igual que hace el copista del manuscrito explicando el mito por la aparición del hombre marino y no por Melusina u otras mujeres con algún tipo de deformidad en la parte inferior del cuerpo. Por otra parte, da igual que Domingo Díaz -el posible copista- no conociese el episodio relatado por Rodolfo de Coggeshall ya que la idea los habitantes

\footnotetext{
${ }^{53}$ Radulphi de Coggeshall Chronicon Anglicanum, fol. 88r-88v en Joseph Stevenson, The Chronicles and Memorials of Great Britain and Ireland during the Middle Ages, London, Longman \& Company, 1875, págs. $117-118$.

${ }^{54}$ Radulphi de Coggeshall Chronicon Anglicanum, fol. 88v en Stevenson, The Chronicles... pág. 118.

${ }_{55}$ No se sabe a que versión de la Vita Sancti Audoeni o pasaje concreto se puede referir aunque después de la lectura de la Vita de este santo se puede establecer una relación entre el episodio del hombre marino y la parte XXI, 53 titulada Qualiter inconditas voces obstrepentium ranarum fecit conticescere vi suorum verborum donde, aparte de hacer callar el ruido de las ranas, Audón declara la ley divina que separa desde el Génesis los animales acuáticos y los terrestres, de ahí que Rodolfo lo mencione ya que un hombre que habita en las profundidades del mar no deja de ser una transgresión del principio de la Creación: Ait enim illis Deus: "Dominamini piscibus maris et volatilibus coeli et omnibus animantibus quae moventur super terram". Item ad Noe et ad filio eius post cataclysmum: "Terror vester ac tremor sir super cuncta animalia terrae et super omnes volucres coeli, cum universis quae moventur in terra". Quod si mutata videatur sententia, non in eis mutata est qui praecepta Dei diligendo custodiunt, se din eis qui praevaricando contemnunt, Vita Sancti Audoeni, XXI, 53 apud E. P. SAuvage (ed.), "Vita S. Audoeni Rotomagensis Episcopi", Analecta Bollandiana, t. V (1886), pág. 129.

56 Jose Manuel Pedrosa, "Las sirenas, o la inmortalidad de un mito (una visión comparatista)", Revista murciana de antropología, 22 (2015), pág. 251.

57 Sobre el estudio de los "habitantes del mar" véase la obra de David Thomson, The People of the Sea: Celtic Tales of the Sea-Folk, Edinburgh, Canongate Books, 2001, págs. 52 y 166-169, uno de los pocos estudios que existen e insuficiente por su apego a la fuente oral y no escrita. Por contexto atlántico se entienden las Islas Británicas hasta la costa de Noruega pasando por Bretaña y especialmente en Irlanda, zonas donde se han catalogado numerosos relatos nobiliarios relacionados con el motivo de la Seal Woman. Gregory Darwin, "On Mermaids, Meroveus, and Mélusine: Reading the Irish Seal Woman and Mélusine as Origin Legend”, Folklore, 126, 2 (2015), págs. 123-124.
} 
del mar -de ambos sexos- eran una constante en las ediciones, por ejemplo, del Hortus Sanitatis que recopilaba las tradiciones de los bestiarios desde el Fisiólogo o Isidoro de Sevilla ${ }^{58}$ en el siglo XV. A finales del siglo que vio aparecer las memorias de Jerónimo del Hoyo, otras evidencias cantábricas apuntaban a una generalización de esta creencia como el hombre-marino de Liérnages comentado y defendido por el Padre Feijoo a pesar de su escepticismo ilustrado ${ }^{59}$.

Como ha comprobado Gregory Darwin los relatos irlandeses comparten un tipo especial de parámetro narratológico como que el caballero se encuentre a una mujer sola y no a un grupo de hombres marinos, que la mujer-sirena (maighdean mara) se vea incapaz de hablar, que el marido la torture para librarla de la mudez y que todas ellas sean origen de linaje para familias de Irlanda y Esco$\mathrm{cia}^{60}$. El relato gallego de los Mariño se inscribe en un ámbito oral marítimo mayor y coherente con la narración y con la intencionalidad de esta como fundación de linaje, si a esto se añaden los testimonios de principios del 1600 sobre los habitantes del mar en Redondela o Coruña se podrá saltar definitivamente la relación con Melusina.

\section{CONCLUSIONES: LA PERVIVENCIA DEL MITO Y SU UTILIDAD}

Lo que provoca el hada o la sirena en su ayuntamiento con el caballero es la diferencia con el linaje de Adán, esto es, romper mediante la continuidad llana y simple para constituir un linaje diferente al resto al estar fundado no por un hombre y una mujer sino por un hombre y una medio mujer ${ }^{61}$ lo cual los Mariño y sus

\footnotetext{
${ }_{58}$ Mientras que para S. Isidoro de Sevilla en las Ethimologiae la sirena es un ser explicable en cuanto alegoría del pecado de los marineros lujuriosos (Etimologiae, XI, 3, 30-31 apud José Oroz Reta y Manuel A. Marcos Casquero (ed.), San Isidoro de Sevilla. Etimologías, Madrid, BAC, 2009, pág. 885) en el Hortus Sanitatis se tiende hacia la credulidad: "Sede et philosophi et sanctorum espositorum nonnulli contrarium sensiunt vera monstra esse dicentes" cap. LXII (Monachus marinus et Monoceros), Cap. LXIV (Nereides et Orcha), cap. LXXXIII (Syrena) en De piscibus apud Antonio ViÑaYo GonZÁlez y Beatriz Riesco Álvarez (ed.), Hortus sanitatis. De Avibus, De piscibus (ed. facs.) León, Universidad de León; Cátedra de San Isidoro de la Real Colegiata, 1998. En otros bestiarios tardomedievales ya aparece como la mujer-pez frente a la mujer-ave de la antigüedad: XL. De propietate serene. Propietas serene est talis quia serene est biformis, quia e medietate supra est ut pulcerrima virgo, deinde infra est ut piscis. Et est triplex species serenarum, quia non habent vocem alique arpe vel viole, et alie canunt sicut tuba vel tibia, et alie canunt sicut virgo. Ita quod homines navegantes propter cantus dulcedinem et melodiam ipsarum sopiuntur et demerguntur in mare, Raúl Gómez PAто (tr. y ed.), Libellus de Natura Animallium $/$ Libriño sobre a natureza dos animais (Un bestiario medieval), Santiago de Compostela, Positivas, 1998, págs. 94-95.

59 Baroja, De los arquetipos..., pág. 176.

${ }^{60}$ Los Conneleys, los Dowds, O'Haras, Gallaghers, O’Sheas o los Hennesseys en Irlanda o los MacCodrum en Escocia testimonian el éxito de esta versión del relato de la sirena. DARwIN, "On Mermaids...", pág. 124. En Irlanda el mito de la sirena ha llegado incluso a venerarse como santa y reliquia lo que da fe de su arraigo folklórico, Pedrosa, "Las sirenas, o la inmortalidad...”, pág. 246.

${ }^{61}$ Véase el relato de cómo se engendró Meroveo debido a un monstruo divino salido del mar. En la Crónica (III, cap.9) de Fredegario del siglo VII apud DARwIN, “On Mermaids...”, pág. 126. Una versión
} 
familias anexas como los Goyanes, Fandiño (Fig. 3) y otros tenían por honra y orgullo no solo mostrado en los Nobiliarios ${ }^{62}$ sino también en el permanente recuerdo heráldico del origen en la sirena.

A pesar de la muerte -parcial- de las hadas solo así -como símbolo- entrarían en la patria alegórica de la heráldica de los Mariños, los Goyanes y algún otro linaje gallego $^{63}$. Si como origen nobiliario la sirena sufrió una crítica discursiva debido a la percepción de lo fantástico, no ocurrió lo mismo con la iconografía del tema que a partir del siglo XVI se difundió con mucho éxito por tratados de nobleza o escudos de casas nobiliarias. Se puede afirmar que al morir el mito escrito se petrificó ésta en las fachadas en una larga vida que llega hasta nuestros días muy cambiada $^{64}$. También cabe pensar que este proceso de petrificación heráldica es,

idéntica a la de Fredegario donde el elemento que salía del mar era un hombre marino, esto es, invirtiendo los roles de género atribuídos en el relato del $L L$, aparece alrededor de 1570 de la mano de Antonio de Torquemada sobre la incredulidad del mito de los Mariño: No quiero que pasemos adelante sin que sepáis una común opinión que se tiene en el reino de Galicia; y es que alli hay un linaje de hombres que llaman los marinos, los cuales se dice y afirma por cosa muy cierta, y ellos no lo niegan, que decienden de uno de estos tritones o pescados que decimos, antes se precian dello. Y aunque se cuenta de diversas maneras, como cosa muy antigua, todas vienen a concluir en que, andando una mujer ribera de la mar entre una espesura de árboles, salió un hombre marino en tierra y, tomándola por fuerza, tuvo sus ayuntamientos libidinosos con ella, de los cuales quedó preñada. Y este hombre o pescado se volvió a la mar y tornaba muchas veces al mesmo lugar a buscar a esta mujer; pero, sintiendo que le ponian asechanzas para prenderle, desapareció. Cuando la mujer vino a parir, aunque la criatura era racional no dejó de traer en sí señales por donde se entendió ser verdad lo que decía que con el tritón le había sucedido. Este negocio es tan antiguo que no me maravillo de que haya en la manera del contarlo diversas opiniones, pues ningún autor lo dice, ni hay dello otro testimonio para que pueda creerse sino la fama pública y común, que lo ha dicho y publicado. Antonio de ToRquemada Jardín de flores curiosas, introducción y edición de Enrique Suárez Figaredo, Lemir, 16 (2012), pág. 666.

${ }^{62}$ Lo qual no lo an por mal antes lo rreziben por onrra deste linaje, Alonso de SANTA Cruz, Segunda parte del libro de blasones del cronista Alonso de Santa Cruz, BNE, ms. 11860, fol. 66r y también en Hernández de Mendoza, Nobiliario Antiguo, Madrid, BNE, ms. 9330, fol. 85v-86r y copia posterior del mismo en BNE, Tratado de Blasones, ms. 10665, págs. 254-255.

${ }^{63}$ Los Goyanes y sobre todo los Lobeiras emparentaron ya con los Mariños en el siglo XIV. Véase el árbol genealógico (aproximado) en González VÁzQUez, El arzobispo de Santiago..., pág. 407. Para una obra actualizada sobre las mujeres en la familia de los Mariños en el siglo XIV véanse las biografías de Sancha Mariño y Sancha Mariño de Lobeira, Eduardo PARdo de Guevara y VALdés (ed.), Mujeres con poder en la Galicia medieval (siglos XIII-XV). Estudios, biografias y documentos, Santiago de Compostela, Instituto de Estudios Gallegos Padre Sarmiento, CSIC-XuGa, 2017 (Anejos de Cuadernos de Estudios Gallegos, 44), págs. 538-550.

${ }^{64}$ El timbre heráldico de la sirena, antigua seña de los Mariño, Goyanes o Lobeira (presente en numerosas construcciones y especialmente en el baldaquino pétreo de Santa María de Caldas de Reis y en el panteón de los Fandiño de Santa María de Beade, Fig. 3) pasó con el diseño del escudo nacionalista de D. A. Rodríguez Castelao a la vida política gallega obviando sus orígenes aristocráticos pero también el mito sobrevivió en otros autores gallegos como Emilia Pardo Bazán o la versión actualizada de Gonzalo Torrente Ballester, José Beloso Gómez, "El mito de las sirenas en El cuento de la sirena de Gonzalo Torrente Ballester”, en José Á. Fernández Roca y José A. Ponte Far, Con Torrente en Ferrol: un poco después, A Coruña, Servicio de Publicacións, 2001, págs. 299-316 y Mercedes MARTí Baldellou, "Breve estudio sobre el cuento de la sirena", en Homenaje a Gonzalo Torrente Ballester, Salamanca, Caja de Ahorros y M. de P. de Salamanca, 1981, págs. 145-162. Para una aproximación como catálogo a la sirena como 


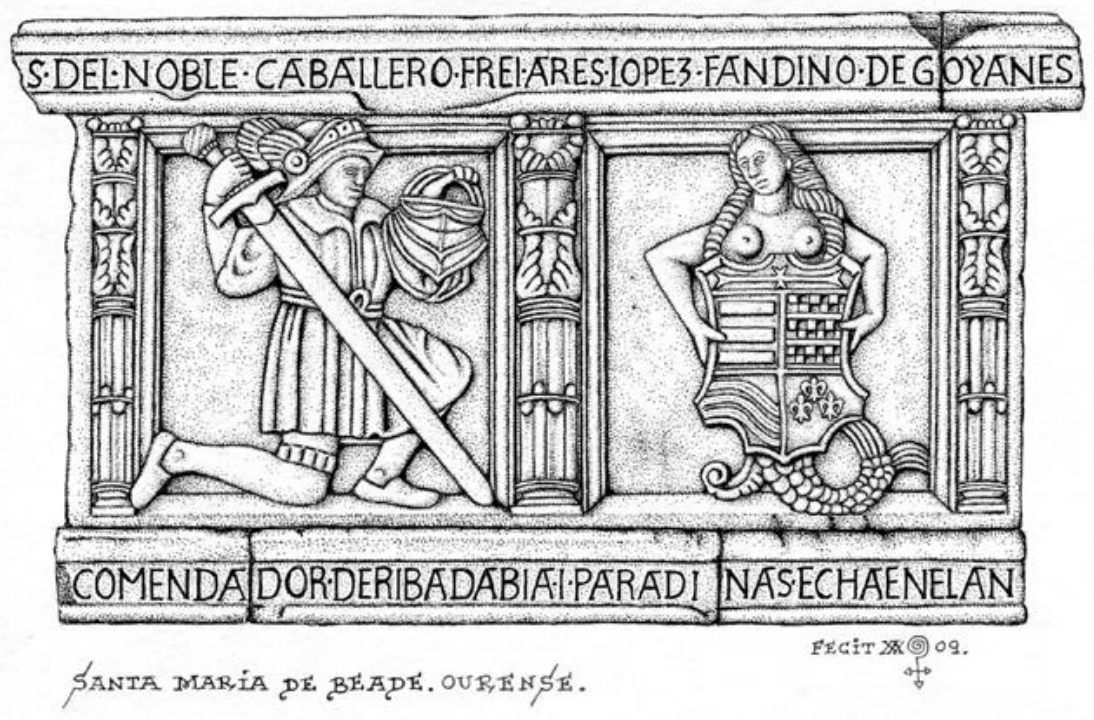

Fig. 3. Frontal de la tumba del comendador Ares Lopez Fandiño de Goyanes en Santa María de Beade (siglo XVI). Colección de dibujos arqueológicos de Xosé Antón García González-Ledo (CSIC-IEGPS), sig. 0383_XI_18.

en realidad, un retorno. Las sirenas a partir del s. XIV se generalizan como tenantes heráldicos, una función que podría provenir del mundo clásico, cuando tritones, nereidas, ninfas o sirenas eran representados portando estandartes o clípeos ${ }^{65}$. Esta explicación debería poner en cuestión si efectivamente la sirena participa en la simbología heráldica como simple tenante, o como emblema parlante de la estirpe o quizás la mitología fundacional partiese precisamente de ese equívoco iconográfico y heráldico. Más bien se podría afirmar que la aparición de la sirena en la heráldica remite directamente al mito fundacional y se convierte en emblema parlante del origen y del nombre de la familia a la que representa, así como del éxito sobre lo monstruoso o teratológico que representaría la sirena.

La inclusión del relato fundacional de los Mariño en las Melusinensagen del resto de Europa es, en cuanto al análisis del discurso, forzado. Se puede hablar más bien de un contexto atlántico en el cual se circunscribe la costa gallega donde el mito de los mujeres y hombres marinos está presente y vivo como se ha expuesto. La lógica del relato de los contactos entre estas gentes del mar y los hu-

emblema heráldico en la arquitectura gallega bajomedieval y moderna véase en Lino J. PAzos, Guía de sirenas de Galicia, Cambados, Gráficas Salnés, 2003, págs. 41-113.

${ }^{65}$ María Isabel Rodríguez López, Mar y mitología en las culturas mediterráneas, Madrid, Alderabán, 1999, pág. 108. 
manos de tierra certifica no solo un intercambio discursivo oral y manuscrito entre las diferentes áreas atlánticas (Bretaña, Inglaterra e Irlanda) sino una legitimación nobiliaria común como lo que se ha dado aquí en llamar "los hijos del mar".

En definitiva, el mito responde a una funcionalidad concreta de la memoria social de un grupo -en este caso una serie de familias- y en absoluto a un orden preestablecido de las cosas o de la naturaleza ambiental. Así, no es una la realidad fáctica y concreta ${ }^{66}$ pero es historia en cuanto perdura, se difunde, muta y a veces muere. Fácticamente imposible pero heterogéneamente real.

\section{APÉNDICE DOCUMENTAL}

Versión moderna del mito de los Mariño con las observaciones de Diego Hernández de Mendoza y glosas posteriores en Diego Hernández de MEndozA, Nobiliario Antiguo, Madrid, BNE, ms. 9330, fol. 85v-86r y copia posterior del mismo en BNE, Tratado de Blasones, ms. 10665, págs. 254-255.

Ay en este Reyno de Galicia otro linaje mui antiguo que llaman Mariños, que quiere decir marítimos, ò hombres de la mar, de suerte que traen este apellido porque dicen quel señor de la Casa desos Cavalleros, yendo un dia orillas de la mar, bio estar unos hombres, i unas mujeres al sol desnudos cerca de una Peña, cubiertos de un cuero grueso, escamoso, i arremetiendo de supito con el caballo los hombres se lanzaron en el mar i cogio la hembra con gran fuerza, i trabajo que tubo con ella, i la llevo a su casa, i hizo curar desa manera que las escamas i cuero duro todo se quito y se volvió mui hermosa, $i$ deprendio a ablar de forma quel caballero la tomo para si de la cual hubo un hijo de la cual descienden estos Mariños y ellos no lo tienen por deshonra antes lo reciven por honra. Ay deste linaje hera el que tubo la contienda que digimos con Garci Perez de Bargas sobre las hondas, bien parece esto cosa de Patraña pues digo que siendo arzobispo de Sanctiago Don Gaspar de Zúñiga i Abellaneda, un año, o dos antes, o después de la quema de Caçalla, siendo yo de siete o ocho años, hubo una gran tormenta en la mar, y un dia después que vino bonanza, salieron los cercos al mar, a pescar la sardina que con tormenta estava en

\footnotetext{
${ }^{66}$ Aquí se utiliza la noción de mito actualizada y ampliada de Roland Barthes cuando afirma que Lontaine ou non, la mythologie ne peut avoir que un fondement historique, car le mythe est une parole choisie par l'histoire: il ne saurait surgir de la «nature» des choses, Roland BARTHES, Le mythe, aujourd'hui en Oeuvres Complètes. Tome I, 1942-1961: Le Degré zéro de l'écriture; Michelet; Mythologies, Paris, Seuil, 2002, pág. 824 .
} 
la Ría, o brazo de mar, y hechadas las redes tomaron en ellas un hombre marino con barvas, i cabello, manos como las nuestras, excepto que no tenía pies, i lo pusieron en una pipa de agua salada para embiarle al Arzobispo de Sanctiago, i me acuerdo contar en casa de mis tíos, del, y decían que no ablava. Estos Mariños son de mi lugar, que es Redondela, y aunque dicen que traen en estas aguas, ellos traen una sirena, con un ligeso en una mano, i la cola como pece, i lo demás como muger. El Mariño yo entiendo que se dice porque se vinieron por la mar de otras tierras, sus armas son tres ondas azules en campo blanco.

\section{BIBLIOGRAFÍA}

Agamben, Giorgio, Profanaciones, Buenos Aires, Adriana Hidalgo, 2013.

Althoff, Gerhard, et alii, Medieval concepts of the Past. Ritual, Memory, Historiography, Cambridge, Washington; German Historical Institute, Cambridge University Press, 2002. Aponte, Vasco de, Recuento de las Casas antiguas del Reino de Galicia, introducción y edición crítica por Manuel C. Díaz y Díaz, et al., Santiago de Compostela, Xunta de Galicia, 1986.

Barreiro Fernández, Xosé R., “A Historia da historia. Aproximación a unha historia galega: de Murguía a Risco", en Justo G. Beramendi (dir.), Galicia e a historiografía, Santiago de Compostela, Tórculo, 1993.

Molina, Bartolomé Sagrario de, Descripción del Reyno de Galicia y de las cosas notables del con las armas y blasones de los linages de Galicia, de donde proceden señaladas Casas en Castilla, 1550, introducción y edición facsímil de José Filgueira Valverde, Santiago de Compostela, Colección de Bibliófilos Gallegos, 1949.

Barthes, Roland, Oeuvres Complètes. Tome I, 1942-1961: Le Degré zéro de l'écriture; Michelet; Mythologies, Paris, Seuil, 2002.

Beceiro Pita, Isabel, "La legitimación del linaje a través de los ancestros", en Jon Andoni Fernández de Larrea y José Ramon Díaz de Durana (eds.) Memoria e Historia. Utilización política en la Corona de Castilla al final de la Edad Media, Madrid, Sílex, 2010, págs. 77-101.

Bermejo Barrera, José Carlos, Sueños para unas sombras. Caminos del mito griego, Santiago de Compostela, Enxebrebooks, 2014.

Baroja, Julio Caro, De los arquetipos y las leyendas, Madrid, Istmo, 1991.

Beloso Gómez, José, "El mito de las sirenas en El cuento de la sirena de Gonzalo Torrente Ballester", en Jose Ángel Fernández Roca y Jose Antonio Ponte Far (eds.) Con Torrente en Ferrol: un poco después, A Coruña, Servicio de Publicacións, 2001, págs. 299-316.

Bennasar, Bartolomé, et alii, Historia Moderna, Madrid, Akal, 1991.

Bietenholz, Peter, Historia and Fabula. Myths and Legends in Historical Thought from Antiquity to the Modern Age, Leiden, New York, Köln; Brill, 1994.

Coumert, Magali, Origines des peuples. Les récits du Haut Moyen Âge occidental (550-850), Paris, Institut d'Études Augustiniennes, 2007, (Collection des Études Augustiniennes, Série Moyen Âge et Temps Modernes-42). 
Cotarelo Valledor, Armando, Cancioneiro de Payo Gómez Charinho almirante y poeta (siglo XIII), Santiago de Compostela, Xunta de Galicia, 1984.

Dacosta, Antonio; Prieto Lasa, José Ramon y Díaz de Durana, José Ramón (eds.) La conciencia de los antepasados: la construcción de la memoria de la nobleza en la Baja Edad Media, Madrid, Marcial Pons, 2014.

Darwin, Gregory, "On Mermaids, Meroveus, and Mélusine: Reading the Irish Seal Woman and Mélusine as Origin Legend", Folklore, 126, 2, (2015), págs. 123-141.

Delpech, François, "Legende de Dona Marinha: Mythologie et genealogie", Cuadernos de Estudios Gallegos, LV, 121 (2008), págs. 407-426.

Dosse, François, La historia en migajas: de Annales a la "Nueva Historia", México D.F., Universidad Iberoamericana, 2006.

Eco, Umberto, La definición del arte, Barcelona, Planeta, 1985.

Faria i Sousa, Manuel (1646) Nobiliario del Conde de Barcelos Don Pedro hijo del rey Don Dionis de Portugal, Madrid, Alonso de Paredes.

Fraguas Fraguas, Antonio, Los colegiales de Fonseca, Santiago de Compostela, Instituto Padre Sarmiento de Estudios Gallegos, CSIC, 1958 (Anejos de Cuadernos de Estudios Gallegos, 12).

Fuentelapeña, Antonio de, El ente dilucidado. Discurso único novíssimo que muestra que ay la naturaleza animales irracionales invisibles y quales sean, Madrid, Imprenta Real, 1676.

Gándara, Felipe de la, Nobiliario armas y triunfos de Galicia, hechos heroicos de sus hijos y elogios de su nobleza, y de la mayor de España y Europa, Madrid, Julián Paredes impresor, 1677.

García Gual, Carlos, Sirenas. Seducciones y metamorfosis, Madrid, Turner, 2014.

García Lomas, G. Adriano, Mitología y supersticiones de Cantabria, Santander, Diputación Provincial de Santander, 1967.

Gibbings, William W., Folk-Lore and Legends. Scotland, London, Constable, 1889.

Godoy Alcántara, José, Historia crítica de los falsos cronicones, Granada, Universidad de Granada, 1999.

González Vázquez, Marta, El arzobispo de Santiago: una instancia de poder en la Edad Media (1150-1400), Sada; Seminario de Estudos Galegos, Ediciós do Castro, 1996.

Gracia Dei, Pedro de, Nobiliario de Gratia Dei, Madrid, BNE, ms. 18053, disponible en <http:// bdh-rd.bne.es/viewer.vm?id $=0000134045 \&$ page $=1>$ [consulta: $25 / 01 / 2019$ ]

Grafton, Anthony, Falsarios y críticos. Creatividad e impostura en la tradición occidental, Barcelona, Crítica, 2001.

Gutiérrez García, Santiago y Lorenzo Gradín, Pilar, Literatura artúrica en Galicia e Portugal na Idade Media, Santiago de Compostela, Universidade de Santiago de Compostela, 2001.

Hernández de Mendoza, Diego, Nobiliario Antiguo, Madrid, BNE, ms.9330, disponible en $<$ http://bdh-rd.bne.es/viewer.vm?id=0000100372\&page $=1>$ [consulta: 10/10/2017]

Hernández de Mendoza, Diego, Tratado de blasones, Madrid, BNE, ms.10665, disponible en $<$ http://bdh-rd.bne.es/viewer.vm?id=0000144136\&page $=1>$ [consulta: 10/10/2017]

Hernández de Mendoza, Diego, Memoriales de linajes, Madrid, BNE, ms.11661, disponible en $<$ http://bdh-rd.bne.es/viewer.vm?id=0000192341\&page=1 $>$ [consulta: 10-10-2017]

Hoyo, Jerónimo del, Memorias del Arzobispado de Santiago: reproducción facsimilar, Santiago de Compostela; Consorcio de Santiago, Universidade de Santiago de Compostela, 2016.

Juaristi, Jon, El bosque originario: genealogías míticas de los pueblos de Europa, Madrid, Taurus, 2000.

Keightley, Thomas, The Fairy Mithology, illustrative of the Romance and Superstition of various Countries, London, George Bell \& Sons, 1892. 
Krus, Luis, Passado, Memória e Poder na Sociedade Medieval Portuguesa. Estudos, Redondo, Patrimonia Historica, 1994.

Krus, Luis, "As origens lendárias dos Condes de Trastâmara", Penélope. Fazer e desfazer a História, 8, (1998), págs. 43-49.

Krus, Luis, "Uma variante peninsular do mito de Melusina: a origem dos Haros no Livro de Linhagens do conde de Barcelos", en A construçâo do passado medieval. Textos inéditos e publicados, Lisboa, Instituto de Estudos Medievais, 2010, págs.151-171.

Ladero Quesada, Miguel Ángel, "No curemos de linaje ni hazanas viejas...": Diego Hernandez de Mendoza y su visión hidalga de Castilla en tiempo de los Reyes Catolicos", Boletín de la Real Academia de la Historia, CXCVIII, 2 (2001), págs. 205-314.

Leclercq Marx, Jacqueline, La Sirène dans la pensé et dans l'art de l'Antiquité et du Moyen Âge. Du mythe païen au symbole chrétien, Bruxelles, Académie Royale de Belgique, 1997.

Le Roy Ladurie, Enmanuel y Le Goff, Jacques, "Mélusine maternelle et défricheuse", Annales. Économies, Sociétés, Civilisations, 26, 3-4, (1971), págs. 587-622.

Libro antiguo de los linajes de Galicia, Madrid, BNE, ms.6329, disponible en <http://bdh.bne. es/bnesearch/CompleteSearchdo?text $=\&$ field 1 val $=\% 22$ Galicia + Genealog $\% \mathrm{C} 3 \% \mathrm{~A}-$ $\mathrm{Da}+\% 22 \&$ showYearItems $=\&$ field $1 \mathrm{Op}=\mathrm{AND} \&$ numfields $=1 \&$ exact $=$ on\&textH $=\&$ advan ced $=$ true $\&$ field $1=$ materia $\&$ completeText $=\&$ pageSize $=1 \&$ pageSizeAbrv $=30 \&$ pageNumber $=1>$ [consulta: $12 / 10 / 2017]$

Llinares García, Mar, Los lenguajes del silencio. Arqueologías de la religión, Madrid, Akal, 2012.

López, Atanasio, "Los falsos cronicones en la historia de Galicia", Nuevos estudios crítico-históricos acerca de Galicia, Madrid; CSIC, Instituto Padre Sarmiento de Estudios Gallegos, 1947, págs.139-173.

Livro de linhagens do Conde Dom Pedro, edición crítica de José Mattoso, Lisboa, Academia das Ciências, 1980 (Portugaliae Monumenta historica: a saecvlo octavo post Christvm vsqve ad qvintvmdecimvn ivssv academiae scietiarivm olisiponensis, Nova Série, vol. II/2).

Martí Baldellou, Mercedes, "Breve estudio sobre el cuento de la sirena", en Homenaje a Gonzalo Torrente Ballester, Salamanca, Caja de Ahorros y M. de P. de Salamanca, 1981, págs. 145-162.

Nikolayevich Viesielovskii, Alexander, Poética histórica, Madrid, Akal, 2014.

Oroz Reta, José y Marcos Casquero, Manuel. A. (eds.), San Isidoro de Sevilla. Etimologías, Madrid, BAC, 2009.

Pardo de Guevara y Valdés, Eduardo, De linajes, parentelas y grupos de poder. Aportaciones a la historia social de la nobleza bajomedieval gallega, Madrid, Fundación Cultural de la Nobleza Española, CSIC, 2012.

Pardo de Guevara y Valdés, Eduardo (ed.), Mujeres con poder en la Galicia medieval (siglos XIII-XV). Estudios, biografias y documentos, Santiago de Compostela, Instituto de Estudios Gallegos Padre Sarmiento, CSIC-XuGa, 2017 (Anejos de Cuadernos de Estudios Gallegos, 44).

Paredes Mirás, María del Pilar, "El simbolismo del hada en la sociedad caballeresca bajomedieval", en Ana Isabel Jiménez Cerrada y José María Arribas Lorenzo (eds.). De los símbolos al orden simbólico femenino (ss. IV-XVII), Madrid, Asociación Cultural Al-Mudayna, 1998.

Paredes Mirás, María del Pilar, Mentalidade nobiliaria e nobreza galega: Ideal e realidade na Baixa Idade Media, Noia, Toxosoutos, 2002.

Pazos, Lino J., Guía de sirenas de Galicia, Cambados, Gráficas Salnés, 2003.

Pedrosa, José M., "Las sirenas, o la inmortalidad de un mito (una visión comparatista)", Revista murciana de antropología, 22 (2015), págs. 239-300. 
Prieto, José. R., Las leyendas de los Señores de Vizcaya y la tradición melusiniana, Madrid; Fundación Ramón Menéndez Pidal, UAM, Universidad del País Vasco, 1995.

Rey Castelao, Ofelia, “As Historias de Galicia na Idade Moderna”, en Isidro Dubert (ed.) Historia das historias de Galicia, Vigo, Xerais, 2016.

Rodríguez López, Isabel, Mar y mitologías en las culturas mediterráneas, Madrid, Alderabán, 1999.

Rosende de Oliveira, António, Trobadores e Xograres. Contexto histórico, Vigo, Xerais, 1995.

Saavedra Rivadeneyra y Aguiar Pardo de Figueroa, Fernando de, Memorial al Rey N. Señor en que se recopila, adiciona, y representa quanto los Coronistas y autores han escrito y consta por instrumentos del origen y antiguedad, descendencia y sucesión, lustre y servicios de la Casa de Saavedra, Granada, Imprenta Real de Francisco de Ochoa, 1674.

Santa Cruz, Alonso de, Segunda parte del libro de blasones del cronista Alonso de Santa Cruz, BNE, ms. 11860, disponible en $<$ http://bdh-rd.bne.es/viewer.vm?id=0000006535\&page=1 $>$ [consulta: 12/10/2017]

Sauvage, E. P. (ed.), "Vita S. Audoeni Rotomagensis Episcopi", Analecta Bollandiana, V, (1886), págs. 67-146.

Souto Cabo, José António (ed.), A História de Don Servando, Santiago de Compostela; Cabido da S.A.M.I. Catedral, Seminario de Estudos Galegos, 2007.

Stevenson, Joseph, The Chronicles and Memorials of Great Britain and Ireland during the Middle Ages, London, Longman \& Company, 1875.

Thomson, David, The People of the Sea: Celtic Tales of the Sea-Folk, Edinburgh, Canongate Books, 2001.

Torquemada, Antonio de, Jardin de flores curiosas, introducción y edición de Enrique Suárez Figaredo, Lemir, 16 (2012), págs. 606-834.

Trueba, Antonio, Leyendas genealógicas de España, Barcelona, Imp. Daniel Cortizo y Comp., 1887.

Valverde Ogallar, Pedro B., Manuscritos y heráldica en el tránsito a la modernidad: el libro de armería de Diego Hernández de Mendoza, Madrid, Universidad Complutense, 2002.

Viñayo González, Antonio y Riesco Álvarez, Beatriz (ed.), Hortus sanitatis. De Avibus, De piscibus, León; Universidad de León, Cátedra de San Isidoro de la Real Colegiata, 1998.

Wood, Christopher S., Forgery, Replica, Fiction. Temporalities of German Renaissance Art, Chicago; Chicago University Press, 2008. 